\title{
Wintertime aerosol chemistry and haze evolution in an extremely polluted city of the North China Plain: significant contribution from coal and biomass combustion
}

\section{Haiyan Li et al.}

Correspondence to: Qiang Zhang (qiangzhang@tsinghua.edu.cn) and Kebin He (hekb@tsinghua.edu.cn)

The copyright of individual parts of the supplement might differ from the CC-BY 3.0 licence. 


\section{Section S1. Analysis to determine the best solution for ME-2}

Using the multi-linear engine (ME-2) implemented with the toolkit SoFi (Source Finder), organic source apportionment was performed with the so-called a value approach. The a value determines the extent to which the resolved factor profiles $\left(\mathrm{f}_{\mathrm{j}, \text { solution }}\right)$ or time series $\left(\mathrm{g}_{\mathrm{i}, \text { solution }}\right)$ are allowed to vary from the input ones (fj, gi) (Canonaco et al., 2013):

$f_{j, \text { solution }}=f_{j} \pm a \cdot f_{j}$, $g_{i, \text { solution }}=g_{i} \pm a \cdot g_{i}$,

To separate an individual HOA factor in addition to CCOA, BBOA and OOA, we only constrained the mass spectra of HOA in this study, using the reference profile from $\mathrm{Ng}$ et al. (2011). Some important criterions to select the optimal solution with a value varying from 0 to 1 are shown in Fig. S2-S6. Generally, increasing a value decreases $\mathrm{Q}$ and the ratio of $\mathrm{Q}$ to $\mathrm{Q}_{\exp }$, due to additional degrees of freedom. However, the size of the change of Q/Qexp over different a values is not significant (Fig. S2a). In addition, the explained variation (EV) could indicate how much variation in each variable is explained by each factor. According to Paatero (2004), a variable should be considered only if the unexplained EV for that variable is less than $25 \%$ (Fig. S2c).

Combining the analysis of factor profiles and time series of each factor across different a values, there is no significant variations for CCOA and OOA. By contrast, with different constraint levels, large changes were found for HOA and BBOA, which were mixed during PMF analysis. As shown in Fig. S3a, moving from a constrained run to a less constrained situation apportioned more signals to larger $\mathrm{m} / \mathrm{z}$ for HOA profile. For a values from 0.2 to 1.0 , fractions of $\mathrm{m} / \mathrm{z}$ smaller than 50 for BBOA profile were significantly enhanced and the time series of BBOA were similar to those of OOA. These results indicated that solutions for a value of 0 and 0.1 were more reasonable. This was further evidenced by the diurnal profiles of each factor and their correlations with external tracers over different a values. To allow some degrees of freedom for model run, we chose the results for a value of 0.1 to be the best solution in this study. 
Table S1. Summary of online measurements $\left(\mu \mathrm{g} / \mathrm{m}^{3}\right)$ using an Aerodyne ACSM or AMS during wintertime in China.

\begin{tabular}{|c|c|c|c|c|c|c|c|c|c|}
\hline Sampling site & Handan, Hebei & Beijing & Beijing & Beijing & Beijing & $\begin{array}{l}\text { Lanzhou, } \\
\text { Gansu }\end{array}$ & $\begin{array}{l}\text { Nanjing, } \\
\text { Jiangsu }\end{array}$ & $\begin{array}{l}\text { Jiaxing, } \\
\text { Zhejiang }\end{array}$ & $\begin{array}{l}\text { Ziyang, } \\
\text { Sichuan }\end{array}$ \\
\hline \multirow[t]{2}{*}{ Location } & $36.57^{\circ} \mathrm{N}$ & $39.99^{\circ} \mathrm{N}$ & $39.97^{\circ} \mathrm{N}$ & $39.97^{\circ} \mathrm{N}$ & $39.97^{\circ} \mathrm{N}$ & $36.05^{\circ} \mathrm{N}$ & $32.05^{\circ} \mathrm{N}$ & $30.8^{\circ} \mathrm{N}$ & $30.15^{\circ} \mathrm{N}$ \\
\hline & $114.50^{\circ} \mathrm{E}$ & $116.31^{\circ} \mathrm{E}$ & $116.37^{\circ} \mathrm{E}$ & $116.37^{\circ} \mathrm{E}$ & $116.37^{\circ} \mathrm{E}$ & $103.85^{\circ} \mathrm{E}$ & $118.77^{\circ} \mathrm{E}$ & $120.8^{\circ} \mathrm{E}$ & $104.64^{\circ} \mathrm{E}$ \\
\hline \multirow[t]{2}{*}{ Period } & Dec.3,2015- & Nov.22- & Nov.21,2011- & Jan.1- & Dec.17,2013- & Jan.10- & Dec.1-31, & Dec.11-23, & Dec.3,2012 \\
\hline & Feb.5, 2016 & Dec.22, 2010 & Jan.20,2012 & Feb.1,2013 & Jan.17,2014 & Feb.4,2014 & 2013 & 2010 & Jan.5,2013 \\
\hline instrument & $\mathrm{ACSM}^{\mathrm{a}}$ & HR-AMS ${ }^{b}$ & ACSM & HR-AMS & HR-AMS & HR-AMS & ACSM & HR-AMS & HR-AMS \\
\hline NR-PM 1 & 173.4 & 63.5 & 66.2 & 89.2 & 63.9 & 53.6 & 90.2 & 34.9 & 52.9 \\
\hline Sulfate & 28.1 & 8.7 & 9.3 & 19.6 & 9.6 & 7.2 & 14.3 & 7.1 & 12.2 \\
\hline Nitrate & 26.1 & 6.8 & 10.6 & 12.5 & 7 & 9.5 & 22.3 & 7.5 & 8.9 \\
\hline Ammonium & 21.4 & 7.7 & 8.6 & 8.9 & 5.1 & 5.9 & 12.5 & 4.9 & 8.2 \\
\hline Chloride & 16.6 & 5.8 & 3.3 & 3.6 & 3.8 & 1.7 & 2.7 & 2.7 & 2.1 \\
\hline Organic & 81.2 & 34.5 & 34.4 & 44.6 & 38.4 & 29.3 & 38.4 & 12.7 & 21.5 \\
\hline HOA & 6 & 4.7 & 5.8 & 4.9 & 3.8 & 2.6 & 5 & 5 & 3.2 \\
\hline $\mathrm{COA}$ & N.D. ${ }^{c}$ & 6.7 & 6.5 & 8.9 & 6.9 & 5.8 & 5 & N.D. & N.D. \\
\hline BBOA & 20.7 & 4.1 & N.D. & N.D. & 3.3 & 3.2 & 5.8 & 3.8 & 3 \\
\hline
\end{tabular}




\begin{tabular}{|c|c|c|c|c|c|c|c|c|c|}
\hline CCOA & 23.1 & 8.2 & 11.4 & 6.7 & 7.6 & 5.3 & N.D. & N.D. & N.D. \\
\hline OOA & 31.4 & N.D. & 10.7 & N.D. & 16.9 & N.D. & N.D. & 3.8 & N.D. \\
\hline SV-OOA & N.D. & N.D. & N.D. & 11.6 & N.D. & 7 & N.D. & N.D. & 7.8 \\
\hline LV-OOA & N.D. & N.D. & N.D. & 12.5 & N.D. & 5.6 & 8.8 & N.D. & 7.5 \\
\hline LO-OOA & N.D. & 4.3 & N.D. & N.D. & N.D. & N.D. & 4.6 & N.D. & N.D. \\
\hline MO-OOA & N.D. & 6.2 & N.D. & N.D. & N.D. & N.D. & 9.2 & N.D. & N.D. \\
\hline Reference & this study & $\begin{array}{l}\text { Hu et al. } \\
\text { (2016a) }\end{array}$ & $\begin{array}{c}\text { Sun et al. } \\
\text { (2013) }\end{array}$ & $\begin{array}{c}\text { Zhang et al. } \\
\text { (2014) }\end{array}$ & $\begin{array}{l}\text { Sun et al. } \\
\text { (2016) }\end{array}$ & $\begin{array}{l}\text { Xu et al. } \\
\text { (2016) }\end{array}$ & $\begin{array}{c}\text { Zhang et al. } \\
\text { (2015) }\end{array}$ & $\begin{array}{l}\text { Huang et al. } \\
\text { (2012) }\end{array}$ & $\begin{array}{l}\text { Hu et al. } \\
\text { (2016b) }\end{array}$ \\
\hline
\end{tabular}

$49{ }^{a}$ Aerosol Chemical Speciation Monitor (ACSM)

$50 \quad{ }^{\mathrm{b}}$ High Resolution Time-of-Flight Aerosol Mass Spectrometer (HR-AMS)

$51 \quad{ }^{c}$ N.D. $=$ not detected.

52 


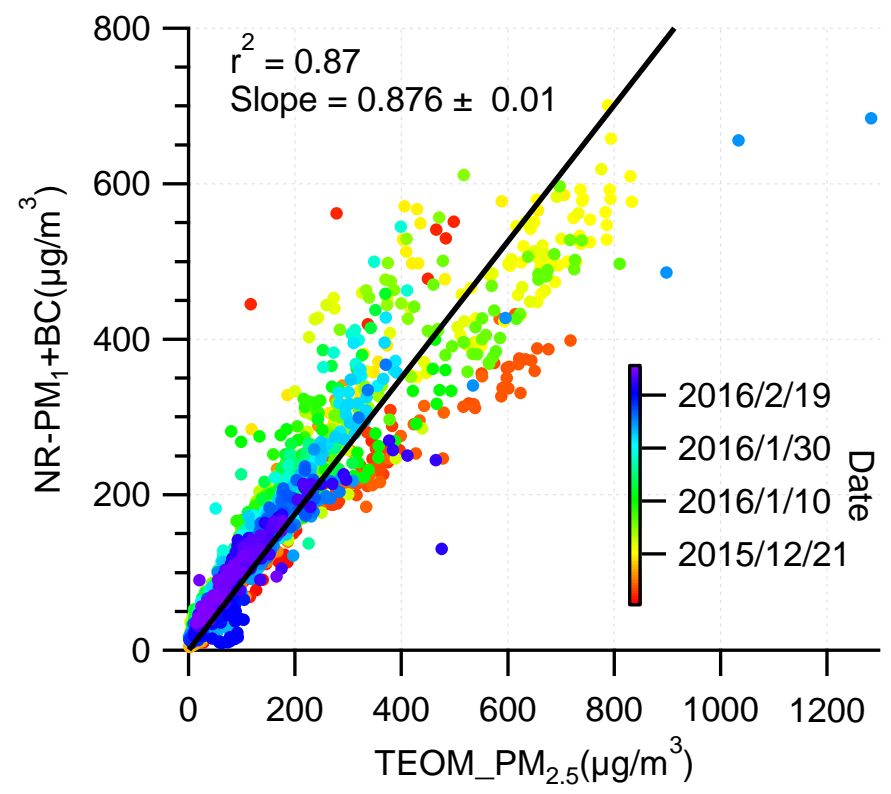

54

Figure S1. Correlation of NR-PM1 measured by ACSM plus BC measured by MAAP with $\mathrm{PM}_{2.5}$ measured by TEOM.

56 
(a)

(b)
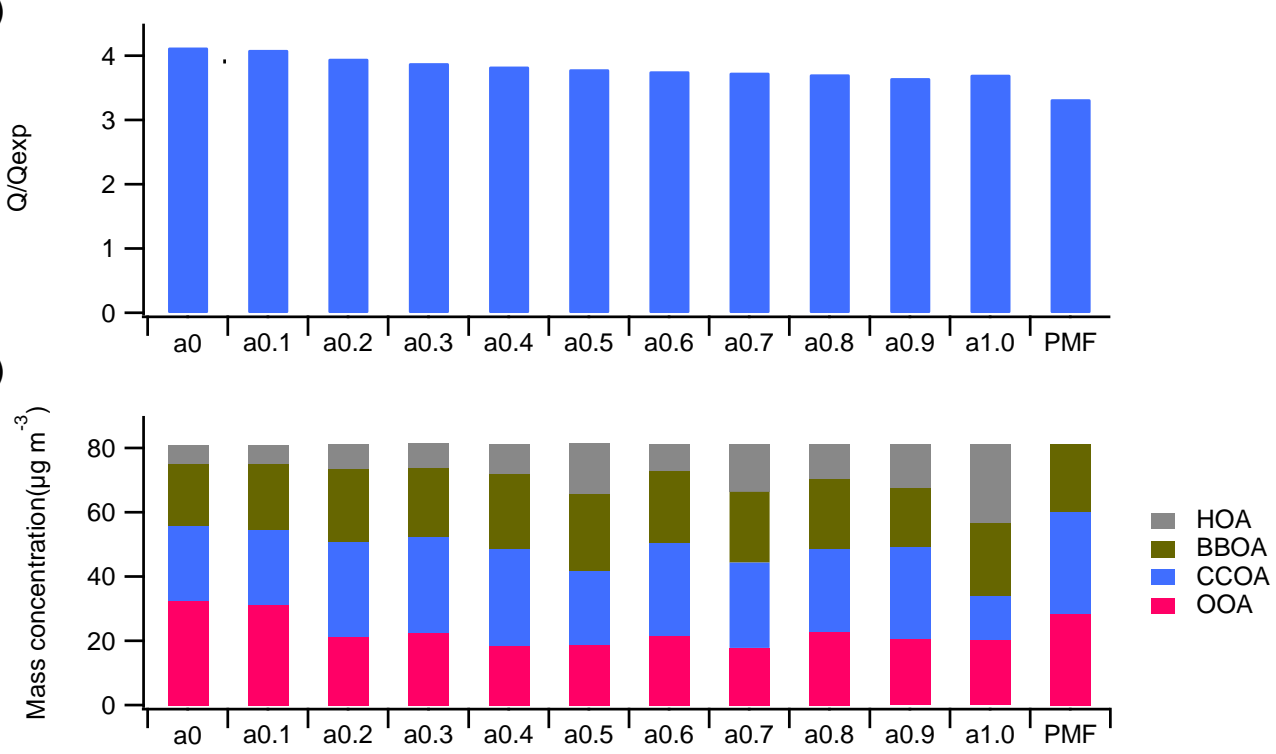

(c)

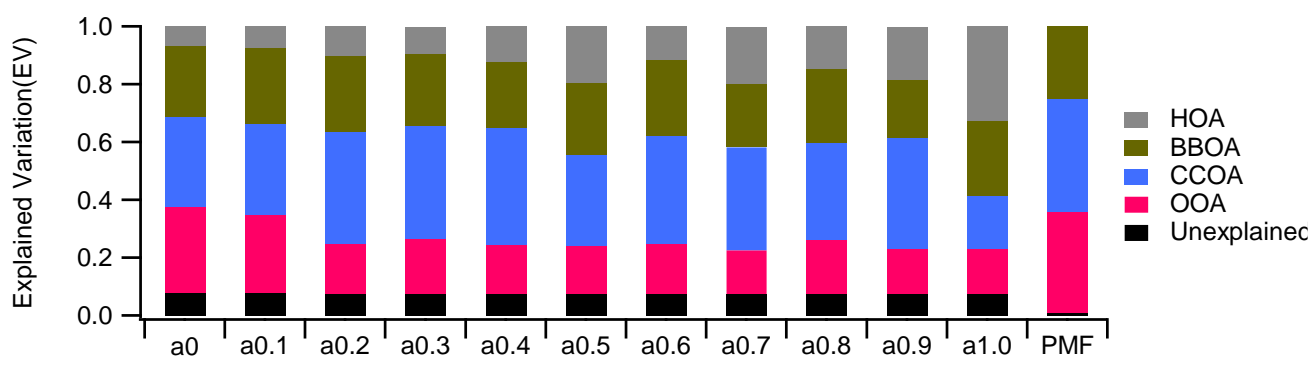

Figure S2. (a) Values of Q/Qexp, (b) mass concentrations of each factor and (c) explained variation (EV) for each factor and total unexplained variation (UEV) for different model runs. The PMF result shown here is for 3factor solution. 
(a)
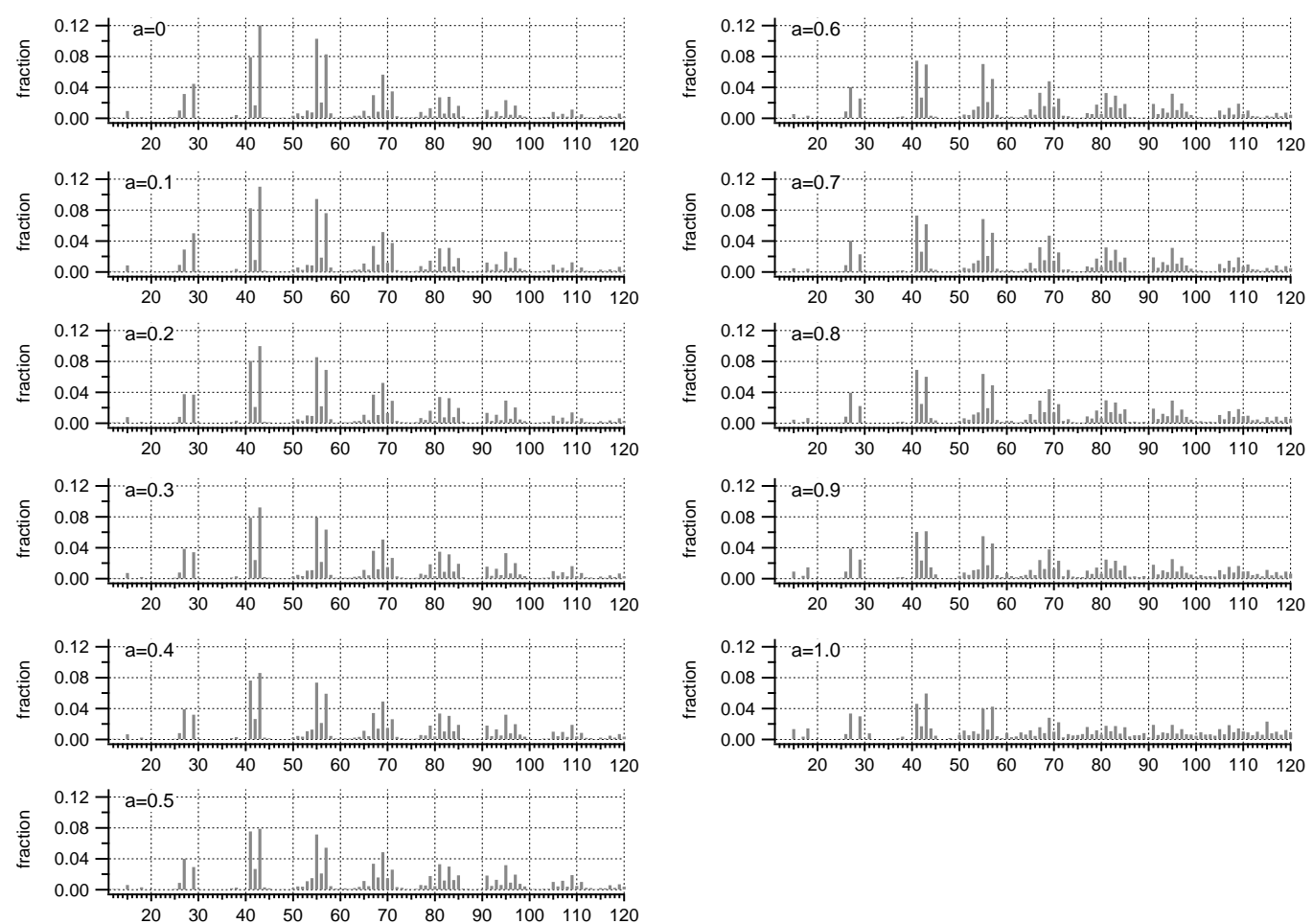
(b)
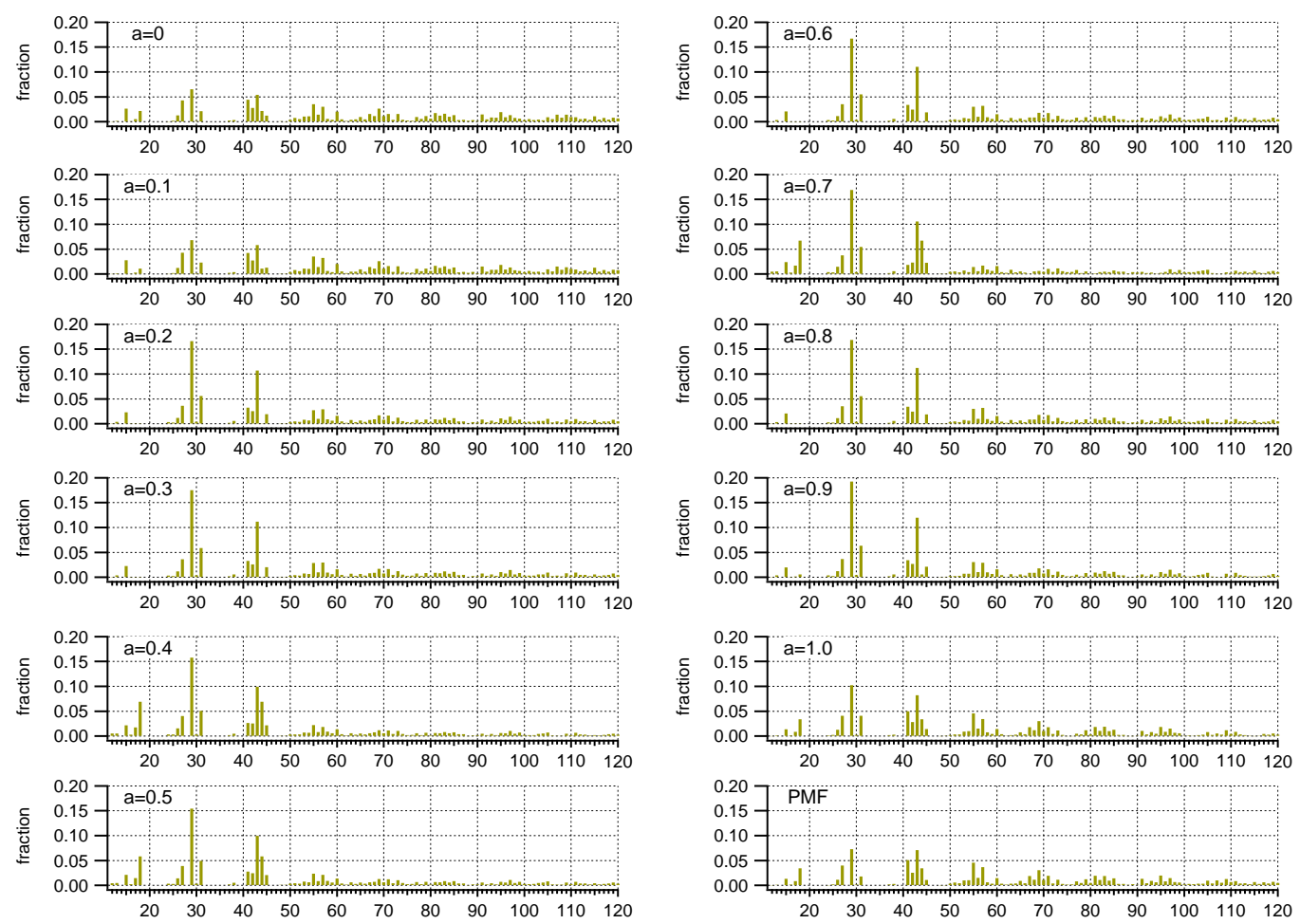
(c)
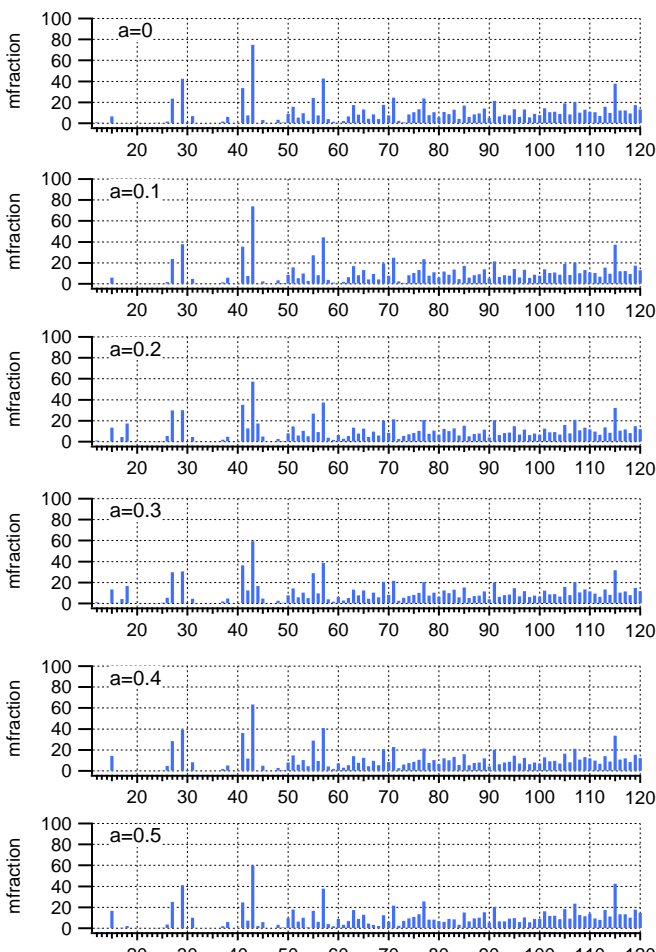
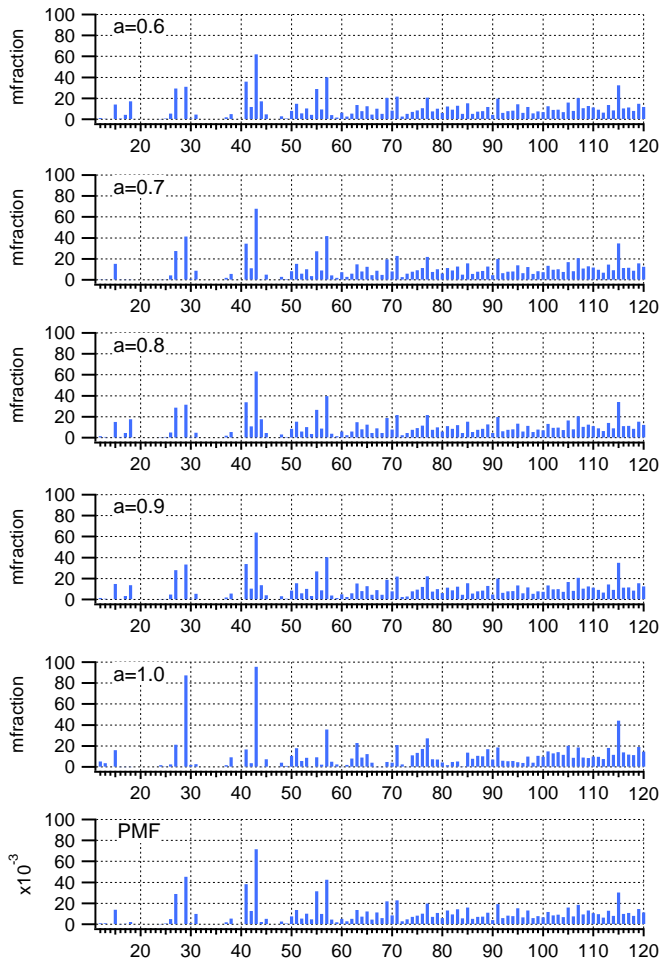
(d)
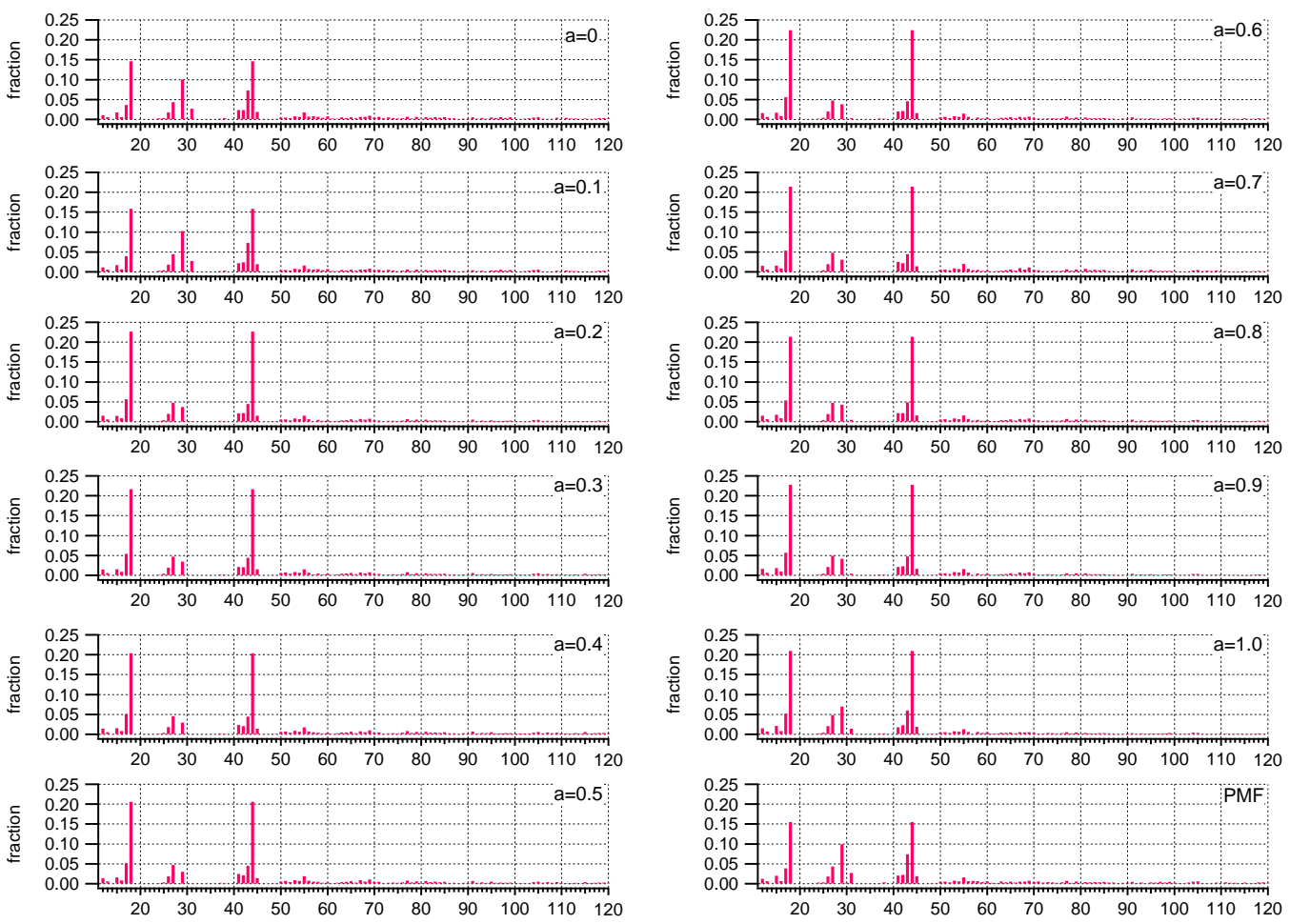

Figure S3. Factor profiles of (a) HOA, (b) BBOA, (c) CCOA and (d) OOA for different model runs 
(a)
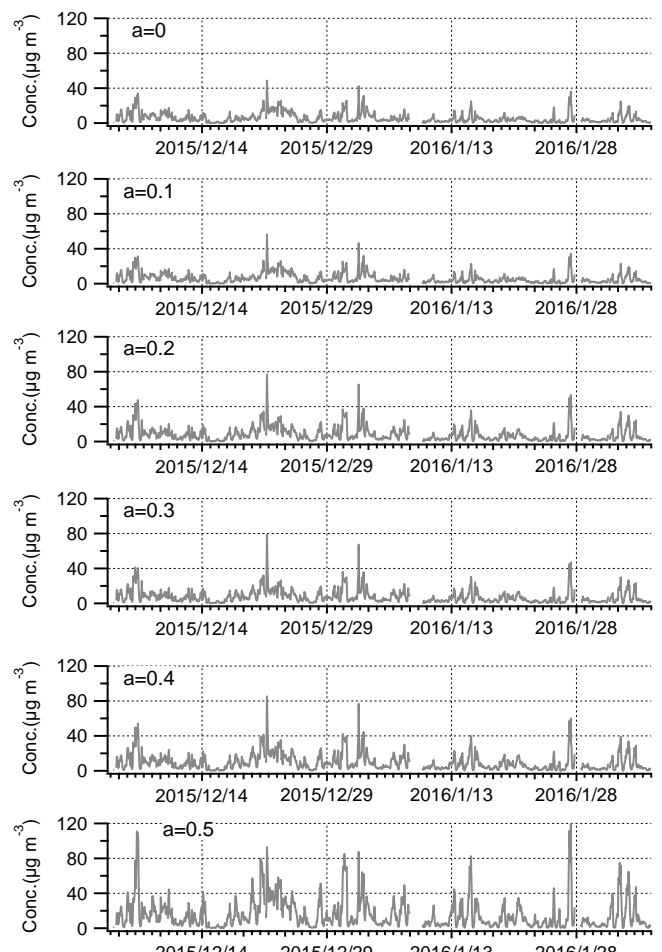

71 $2015 / 12 / 14 \quad 2015 / 12 / 29 \quad 2016 / 1 / 13 \quad 2016 / 1 / 28$
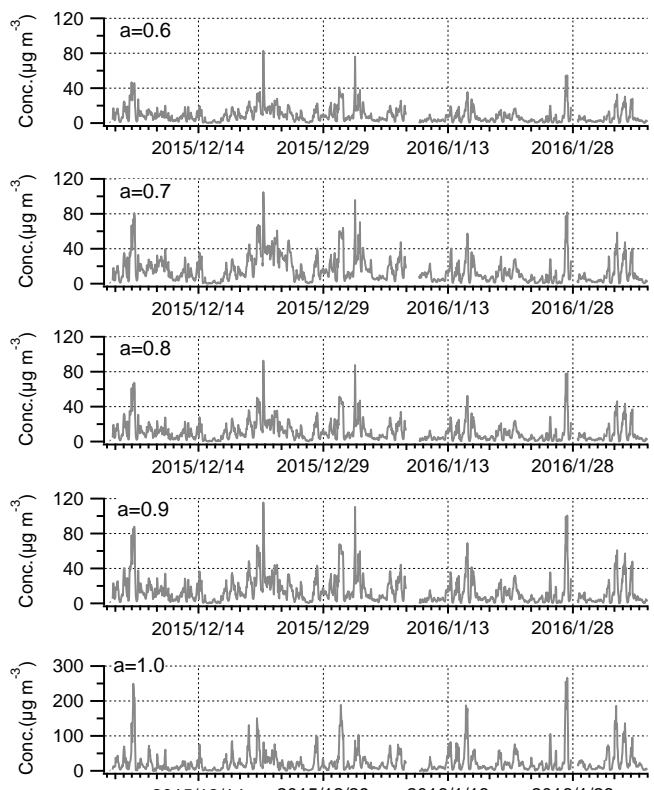
$\begin{array}{llll}2015 / 12 / 14 & 2015 / 12 / 29 & 2016 / 1 / 13 & 2016 / 1 / 28\end{array}$ 
(b)
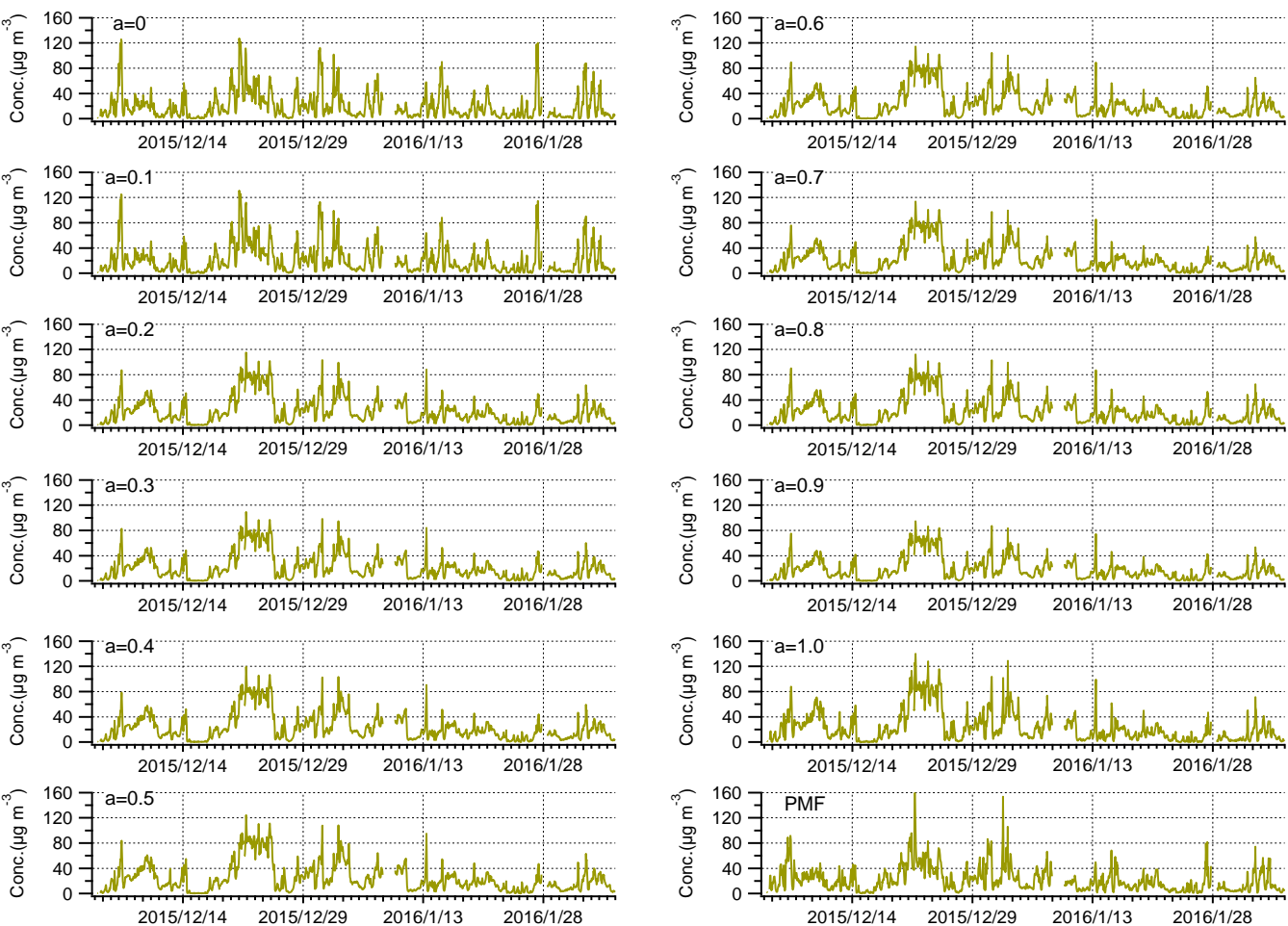
(c)
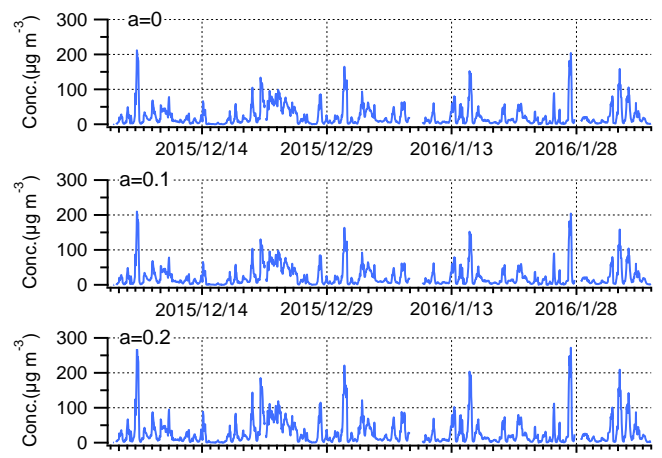
$2015 / 12 / 14 \quad 2015 / 12 / 29 \quad 2016 / 1 / 13 \quad 2016 / 1 / 28$
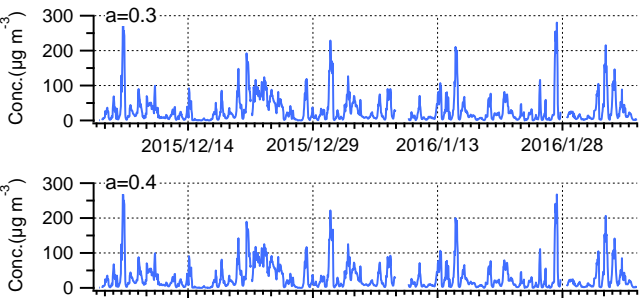
$2015 / 12 / 142015 / 12 / 292016 / 1 / 13 \quad 2016 / 1 / 28$

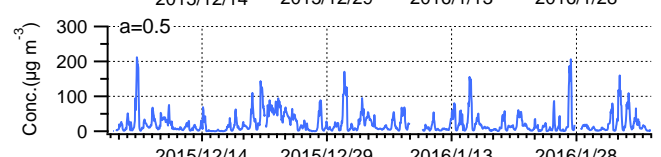
$2015 / 12 / 14 \quad 2015 / 12 / 292016 / 1 / 13 \quad 2016 / 1 / 28$
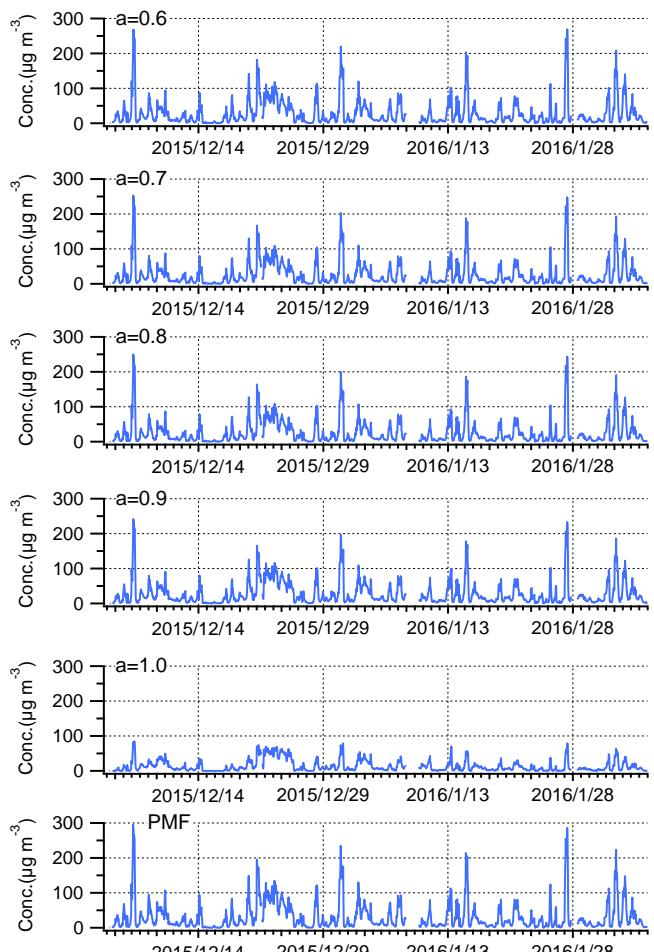
(d)
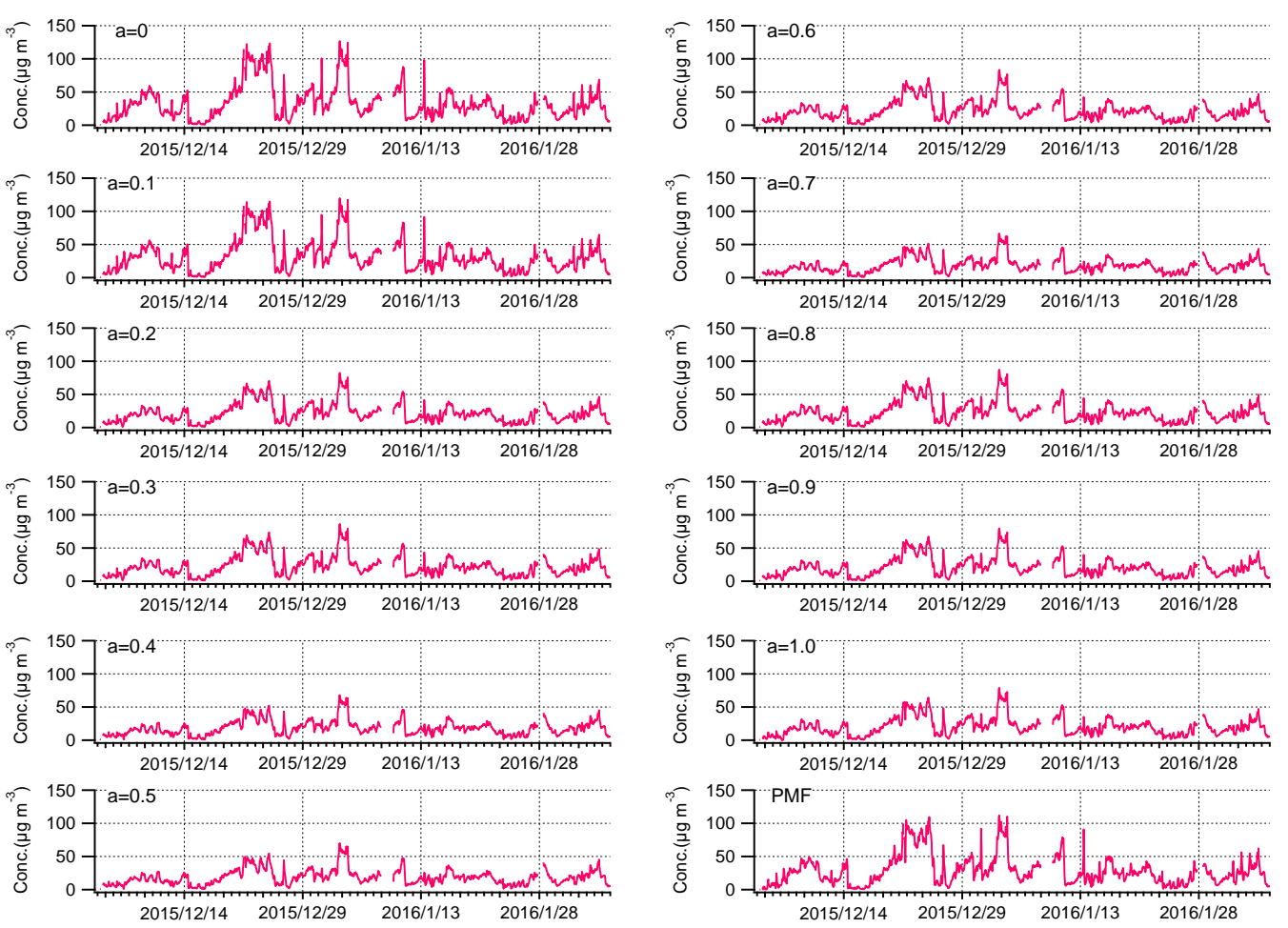

Figure S4. Time series of (a) HOA, (b) BBOA, (c) CCOA and (d) OOA for different model runs. 

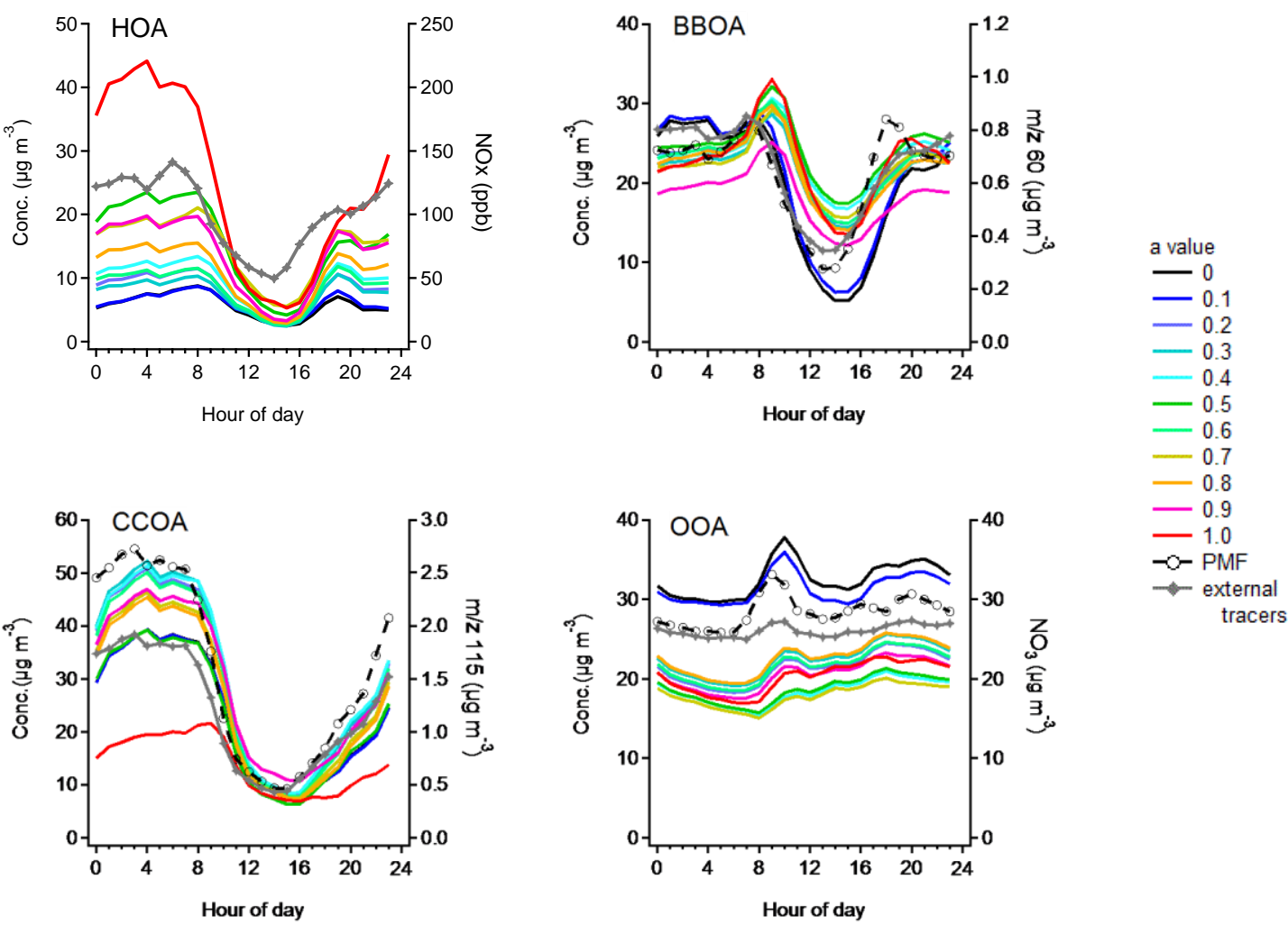

Figure S5. Mean diurnal variations of HOA, BBOA, CCOA and OOA for different model runs, with the variations of their external tracers on the right axis. 

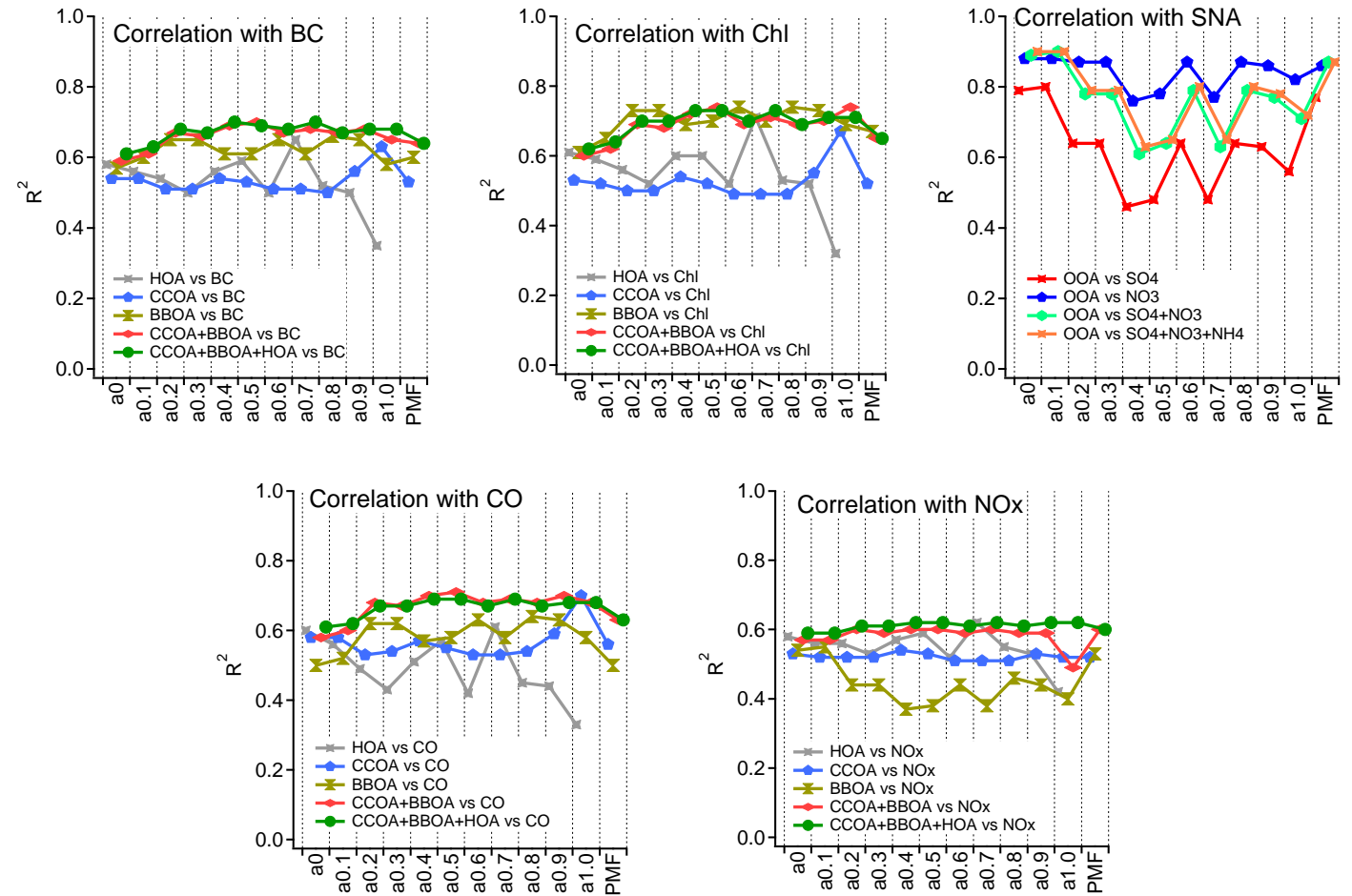

Figure S6. Correlations $\mathrm{R}^{2}$ (Pearson) between the time series of OA factors and the time series of external tracers as a function of model runs. 

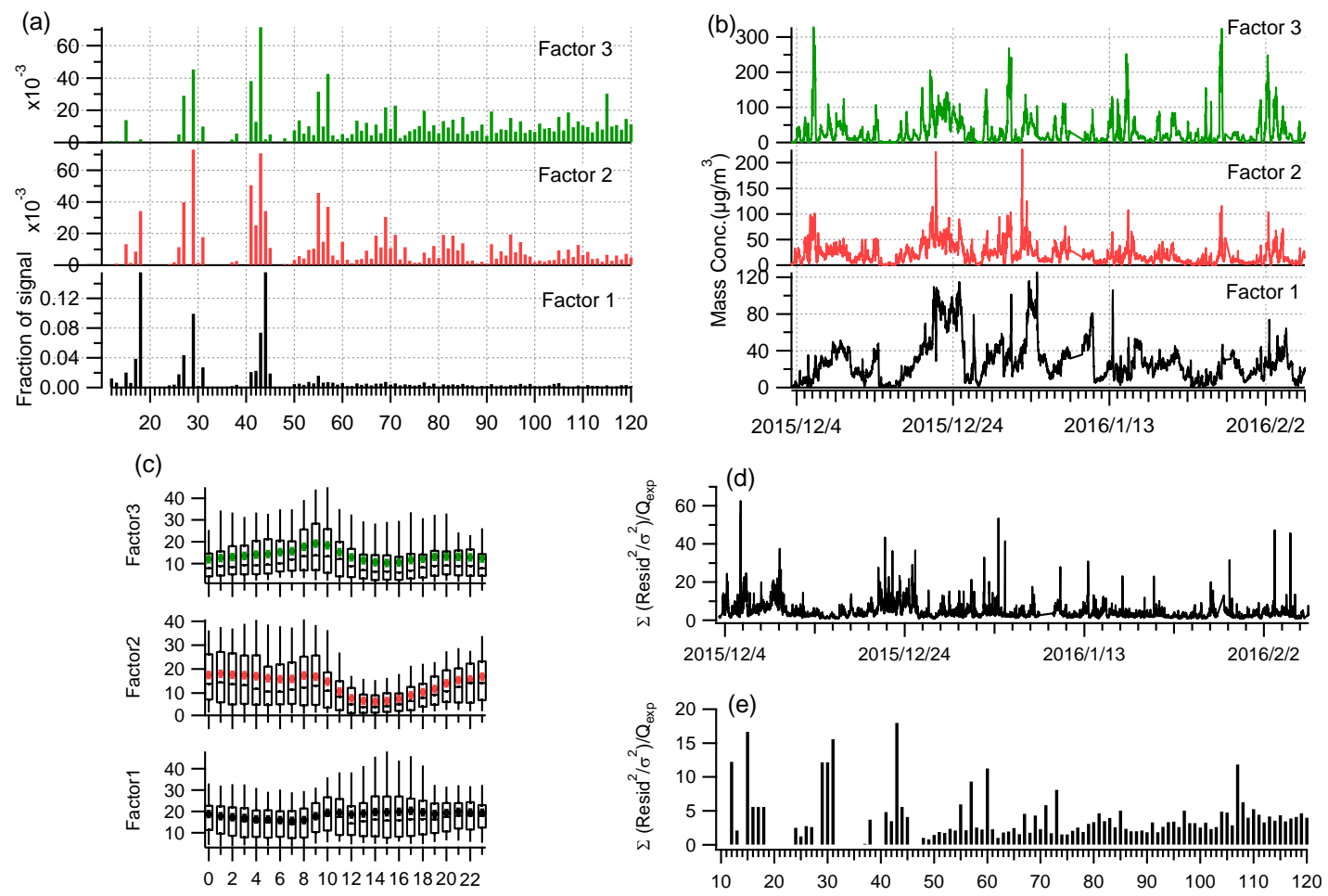

Figure S7. (a) Spectral profiles, (b) time series, (c) diurnal patterns, (d) time series of Q/Qexp, and (e) spectral profile of Q/Qexp for 3-factor solution of PMF analysis. 

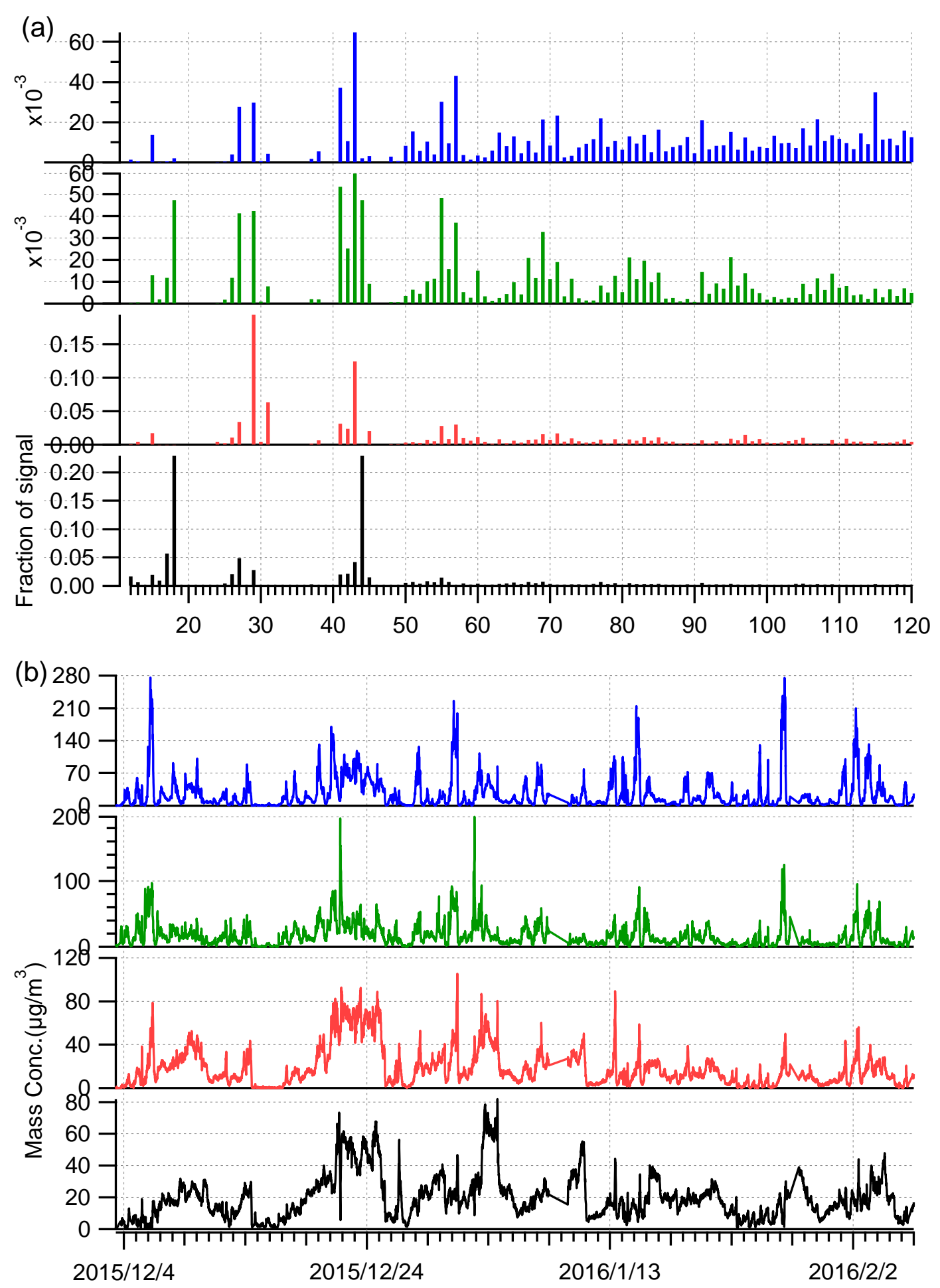

Figure S8. (a) Spectral profiles and (b) time series for 4-factor solution of PMF analysis. 


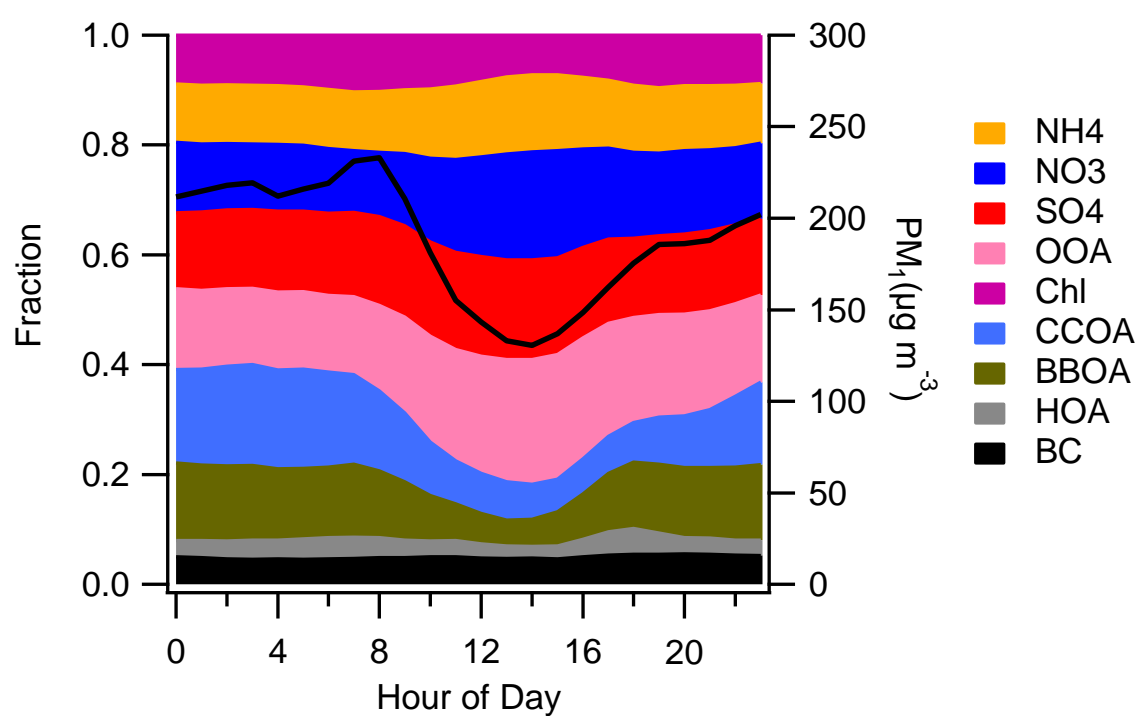

95 Hour of Day

Figure S9. Average diurnal cycles of the mass fractions of aerosol species. 
(a)

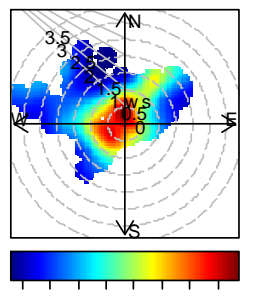

$\begin{array}{llll}10 & 30 & 50 & 70\end{array}$ $\mathrm{PM}_{1}\left(\mu \mathrm{g} \mathrm{m}^{-3}\right)$

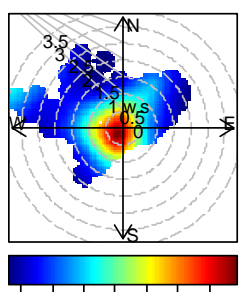

$\begin{array}{lllllll}1 & 2 & 3 & 4 & 5 & 6 & 7\end{array}$ $\mathrm{BC}\left(\mu \mathrm{g} \mathrm{m}^{-3}\right)$

(b)

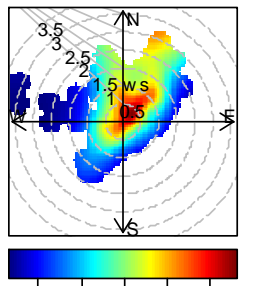

50100150200250 $\mathrm{PM}_{1}\left(\mu \mathrm{g} \mathrm{m}^{-3}\right)$

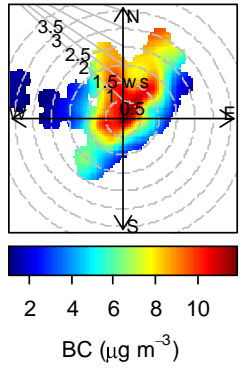

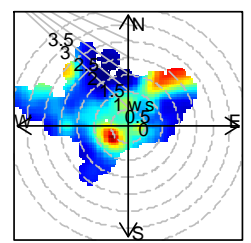

$\begin{array}{lllllll}2 & 4 & 6 & 8 & 10 & 12 & 14\end{array}$ $\mathrm{SO} 4\left(\mu \mathrm{g} \mathrm{m}^{-3}\right)$

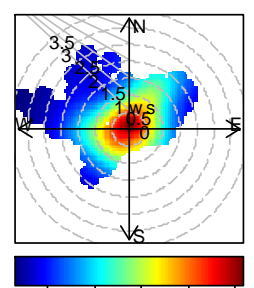

$\begin{array}{lllll}0.5 & 1 & 1.5 & 2 & 2.5\end{array}$ $\mathrm{HOA}\left(\mu \mathrm{g} \mathrm{m}^{-3}\right)$

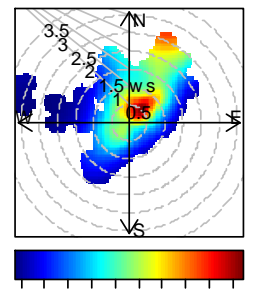

$\begin{array}{lllll}10 & 20 & 30 & 40 & 50\end{array}$ $\mathrm{SO} 4\left(\mu \mathrm{g} \mathrm{m}^{-3}\right)$

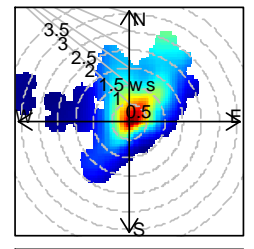

123456789 HOA $\left(\mu \mathrm{g} \mathrm{m}^{-3}\right)$

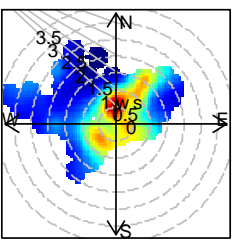

$\begin{array}{llllll}2 & 4 & 6 & 8 & 10 & 12\end{array}$ $\mathrm{NO}_{3}\left(\mu \mathrm{g} \mathrm{m}^{-3}\right)$
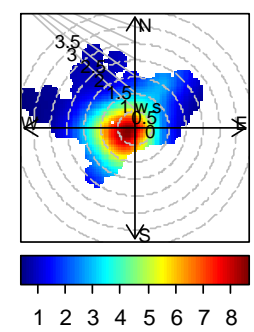
BBOA $\left(\mu \mathrm{g} \mathrm{m}^{-3}\right)$

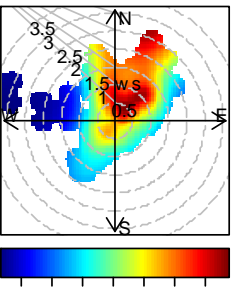

5101520253035 $\mathrm{NO}_{3}\left(\mu \mathrm{g} \mathrm{m}^{-3}\right)$

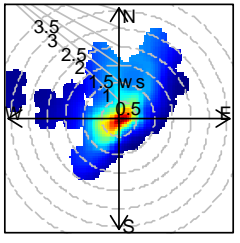

5101520253035 BBOA $\left(\mu \mathrm{g} \mathrm{m}^{-3}\right)$
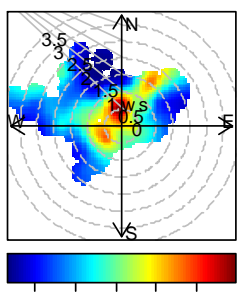

$\begin{array}{lllll}2 & 4 & 6 & 8 & 10\end{array}$ $\mathrm{NH} 4\left(\mu \mathrm{g} \mathrm{m}^{-3}\right)$
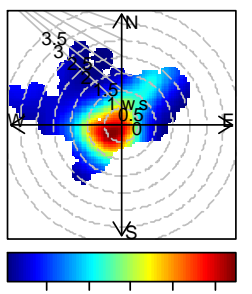

$\begin{array}{lllll}2 & 4 & 6 & 8 & 10\end{array}$ $\operatorname{CCOA}\left(\mu \mathrm{g} \mathrm{m}^{-3}\right)$

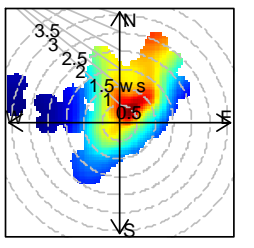

\begin{tabular}{llllll}
\hline & 1 & 1 & 1 & 1 & 1
\end{tabular} $\mathrm{NH} 4\left(\mu \mathrm{g} \mathrm{m}^{-3}\right)$
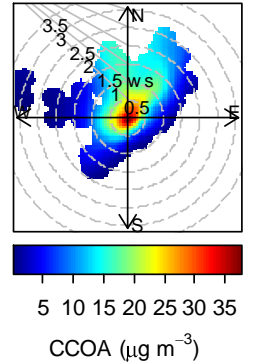

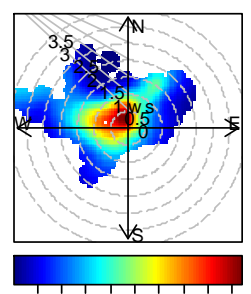

123456789 $\mathrm{Chl}\left(\mu \mathrm{g} \mathrm{m}^{-3}\right)$

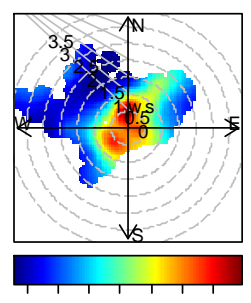

$\begin{array}{llllll}2 & 4 & 6 & 8 & 10 & 1214\end{array}$ OOA $\left(\mu \mathrm{g} \mathrm{m}^{-3}\right)$
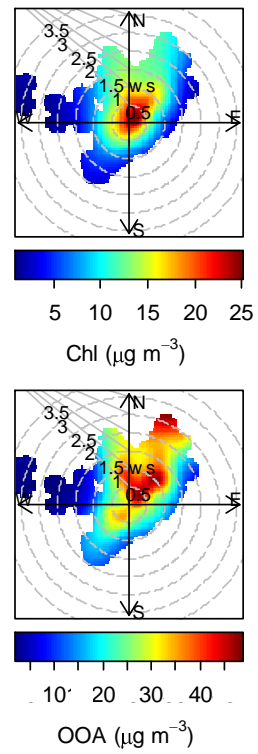

Figure S10. Polar plots of aerosol components as a function of wind speed and wind direction for (a) non- 

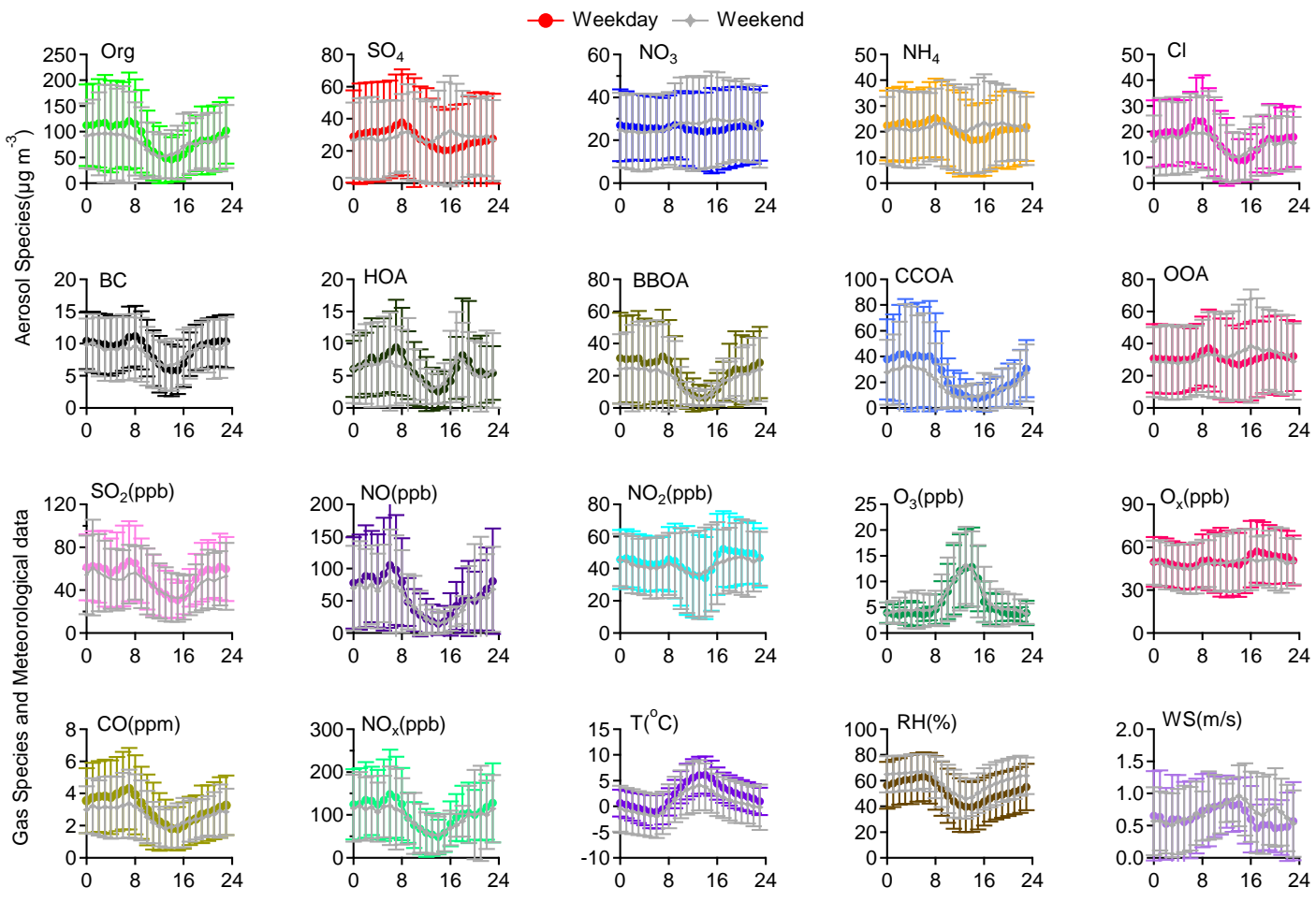

Figure S11. Average diurnal profiles along with the standard deviation of $\mathrm{PM}_{1}$ species, four OA factors identified from PMF analysis, various gas-phase species, and meteorological parameters for weekdays (Monday to Friday inclusive) and weekends (Saturday and Sunday) during the campaign. 
(a)

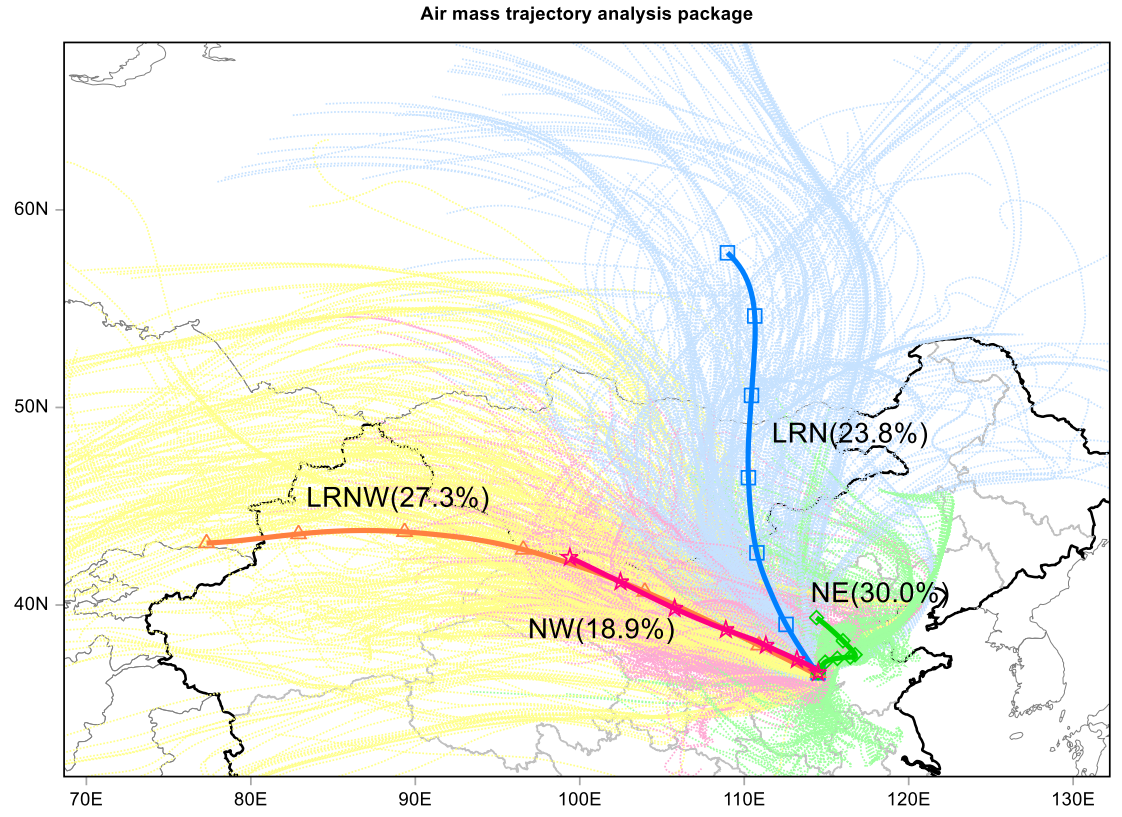

(b)

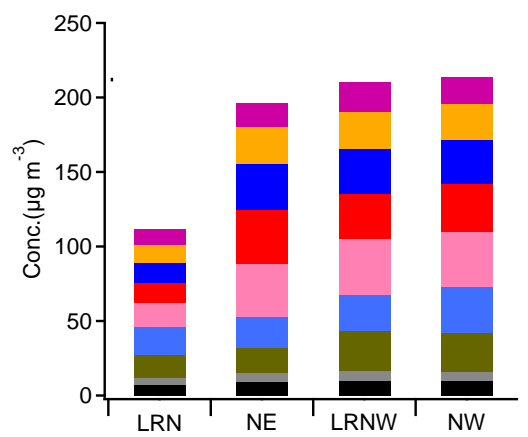

(c)

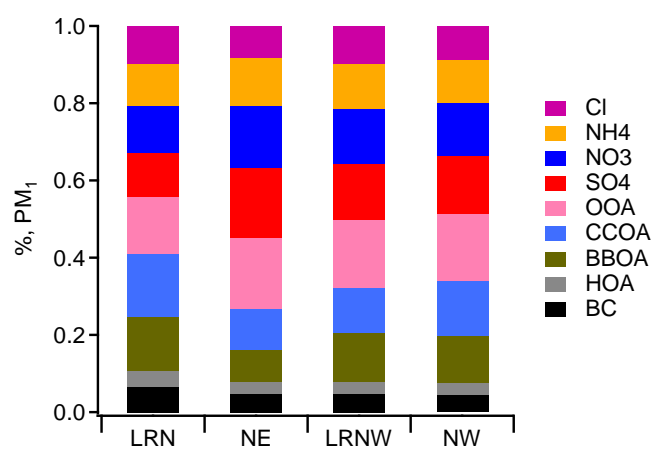

Figure S12. (a) Back trajectories of air masses arriving at Handan every hour for $500 \mathrm{~m}$ above ground level and four clusters determined using the inbuilt function of HYSPLIT for the entire campaign. The four clusters represent air masses long-range transported from the north (LRN, 23.8\%), from the northeast (NE, 30.0\%), from the northwest (NW, 18.9\%), and long-range transported from the northwest (LRNW, 27.3\%). (b) Mass concentrations and (c) mass fractions of aerosol species for each cluster. 


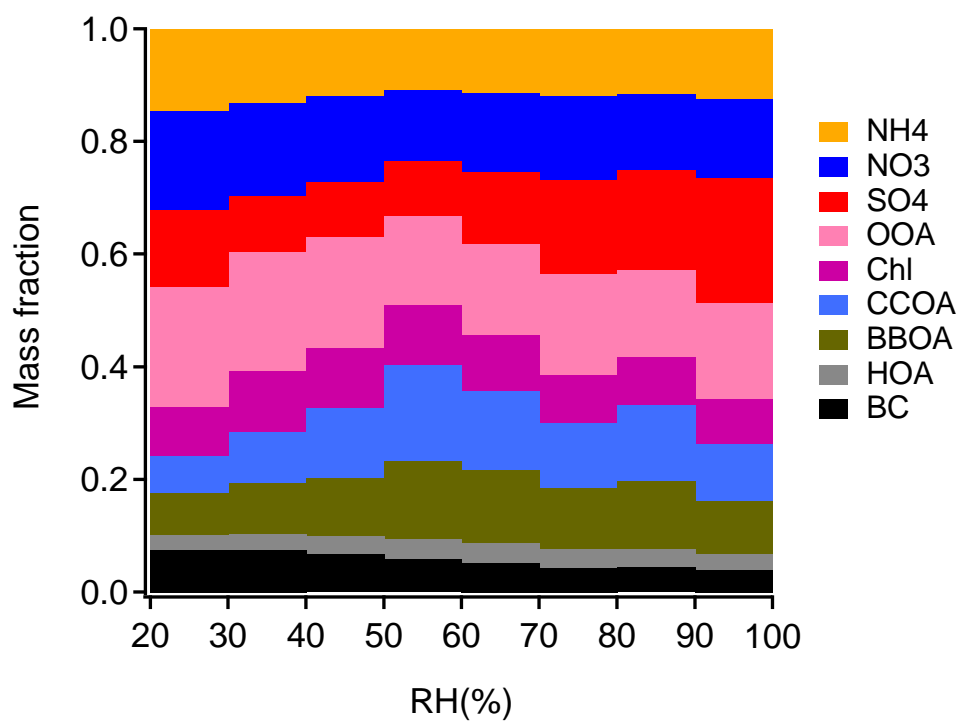

113

Figure S13. The RH-binned bulk composition of submicron aerosols.

114 
116

Hu, W., Hu, M., Hu, W., Jimenez, J. L., Yuan, B., Chen, W., Wang, M., Wu, Y., Chen, C., Wang, Z., Peng, J., Zeng, L., and Shao, M.: Chemical composition, sources and aging process of submicron aerosols in Beijing: contrast between summer and winter, J. Geophys. Res., 121, 1955-1977, doi:10.1002/2015JD024020, 2016a.

Hu, W., Hu, M., Hu, W.-W., Niu, H., Zheng, J., Wu, Y., Chen, W., Chen, C., Li, L., Shao, M., Xie, S., and Zhang, Y.: Characterization of submicron aerosols influenced by biomass burning at a site in the Sichuan Basin, southwestern China, Atmos. Chem. Phys., 16, 13213-13230, doi:10.5194/acp-16-132132016, 2016 b.

Huang, X. F., Xue, L., Tian, X. D., Shao, W. W., Sun, T. L., Gong, Z. H., Ju, W. W., Jiang, B., Hu, M., and He, L. Y.: Highly time-resolved carbonaceous aerosol characterization in Yangtze River Delta of China: Composition, mixing state and secondary formation, Atmos. Environ., 64, 200-207, doi:10.1016/j.atmosenv.2012.09.059, 2013.

Ng, N. L., Canagaratna, M. R., Jimenez, J. L., Zhang, Q., Ulbrich, I. M., and Worsnop, D. R.: Real-time methods for estimating organic component mass concentrations from aerosol mass spectrometer data, Environ. Sci. Technol., 45, 910-916, 2011.

Paatero, P.: User's guide for positive matrix factorization programs PMF2 and PMF3, 2004.

Sun, Y. L., Wang, Z. F., Fu, P. Q., Yang, T., Jiang, Q., Dong, H. B., Li, J., and Jia, J. J.: Aerosol composition, sources and processes during wintertime in Beijing, China, Atmos. Chem. Phys., 13, $4577-$ 4592, doi:10.5194/acp-13-4577-2013, 2013.

Sun, Y., Du, W., Fu, P., Wang, Q., Li, J., Ge, X., Zhang, Q., Zhu, C., Ren, L., Xu, W., Zhao, J., Han, T., Worsnop, D. R., and Wang, Z.: Primary and secondary aerosols in Beijing in winter: sources, variations and processes, Atmos. Chem. Phys., 16, 8309-8329, doi:10.5194/acp-16-8309-2016, 2016.

Xu, J., Shi, J., Zhang, Q., Ge, X., Canonaco, F., Prévôt, A. S. H., Vonwiller, M., Szidat, S., Ge, J., Ma, J., An, Y., Kang, S., and Qin, D.: Wintertime organic and inorganic aerosols in Lanzhou, China: Sources, processes and comparison with the results during summer, Atmos. Chem. Phys. Discuss., doi:10.5194/acp-2016-278, in review, 2016.

Zhang, J. K., Sun, Y., Liu, Z. R., Ji, D. S., Hu, B., Liu, Q., and Wang, Y. S.: Characterization of submicron aerosols during a month of serious pollution in Beijing, 2013, Atmos. Chem. Phys., 14, 2887-2903, doi:10.5194/acp-14-2887-2014, 2014.

Zhang, Y. J., Tang, L., Yu, H., Wang, Z., Sun, Y., Qin, W., Chen, W., Chen, C., Ding, A., Wu, J., Ge, S., Chen, C., and Zhou, H.-C.: Chemical composition, sources and evolution processes of aerosol at an urban site in Yangtze River Delta, China during wintertime, Atmos. Environ., 123, 339-349, doi:10.1016/j.atmosenv.2015.08.017, 2015. 